\title{
Modelling of consumption and assimilation in the deposit-feeding polychaete Eupolymnia nebulosa
}

\author{
A. Grémare ${ }^{1}$, J. M. Amouroux ${ }^{1}$, J. Amouroux ${ }^{2}$ \\ ${ }^{1}$ Laboratoire Arago, F-66650 Banyuls/mer, France \\ 2 ENSCP, Université Paris VI, F-75005 Paris, France
}

\begin{abstract}
The deposit-feeding terebellid polychaete Eupolymnia nebulosa was fed over 3 different time periods $\left(4,10\right.$, and $48 \mathrm{~h}$ ) on 3 species of different-sized ${ }^{14} \mathrm{C}$-labelled diatoms: Navicula incerta, Nitzschia acicularis and Nitzschia sp. Because of the complexity of the exchanges of matter between the different compartments (annelids, $\mathrm{CO}_{2}, \mathrm{DOM}$, algae) of the 'Diatom-Annelid' system, the experimental study alone was insufficient to quantify the amounts of organic matter that were ingested, consumed or assimilated by the worms. An analog model allowed quantification of such exchanges. E. nebulosa ingested Nitzschia sp. rather than $N$. acicularis and $N$. incerta. Comparison of results in the presence and absence of annelids suggested that the activity of the worms affected the metabolism of the sedimented diatoms ( $N$. incerta was stimulated whereas $N$. acicularis was inhibited). This action is similar to the effect of the deposit-feeding bivalve Abra alba on these 2 algae.
\end{abstract}

\section{INTRODUCTION}

Food resources available to deposit-feeding organisms are diverse. They include both live cells such as benthic diatoms (Smith et al. 1985) and bacteria (Lopez \& Cheng 1983), and detritus such as sedimenting phytoplankton (Graf et al. 1982, 1984, Christensen \& Kanneworff 1985) and seaweed detritus (Adams \& Angelovic 1970, Stuart et al. 1981, Tenore 1981). Many deposit-feeders are also able to reingest their own faeces (Hylleberg 1975), and/or incorporate dissolved organic matter (DOM) (Stephens 1968). In addition, through bioturbation and predation, deposit-feeders affect the balance of the benthic microorganism community. In the field, the production of microalgae and bacteria is often stimulated in the presence of depositfeeders (Hargrave 1970, Branch \& Pringle 1987). Such complex interactions between deposit-feeders and their food sources, coupled with the heterogeneity of these food sources, complicate the characterization and quantification of organic matter obtained from sediment by benthic deposit-feeders.

Radiotracer methods have been widely used for qualitative and quantitative studies of the portion of organic matter associated with the sediment that is actually ingested and absorbed by deposit-feeders (Adams \& Angelovic 1970, Tenore 1981, Guidi \& Tito de Morais 1983, Guidi 1986). However, the interpretation of such studies is often complicated by short-term recycling phenomena occurring inside closed experimental chambers (Conover \& Francis 1973, Smith \& Horner 1981). The loss of algal specific activity, for example, has been studied by several authors (Mague et al. 1980, Amouroux \& Amouroux 1986b). Because most marine invertebrates are able to incorporate DOM (Stephens 1968), this factor also complicates quantitative studies of nutrition (Smith \& Horner 1981).

It is possible to use an open, instead of a closed system, in order to avoid such bias. Pulse chase experiments are designed to minimize recycling by using very short ingestion periods (Kofoed 1975, Cammen 1980, Lopez \& Cheng 1983; but see Calow \& Fletcher 1972), moving the animal to unlabelled food, and then measuring specific activities of animals and faeces. Such an approach has been useful in estimating ingestion and absorption rates in several benthic depositfeeders. However, such an approach cannot be used with large soft-body tentaculate deposit-feeders (such as the terebellid polychaete Eupolymnia nebulosa Montagul because of: (1) their fragility, (2) timeperiods involved in feeding activities (according to the results of the present study, E. nebulosa, for example, may begin to feed only several hours after the introduction of the food in the experimental chamber) 
Dring \& Jewson (1982) recommended the use of compartmental analysis (i.e. measurement of the temporal changes in radioactivity within several compartments of a closed system) coupled with analog modelling (which allows the a posteriori quantification of exchanges between compartments) for such studies. Our research group has already used this approach for: (1) a 'bacteria - filter-feeder' system (Venus verrucosa + Lactobacillus sp.; Amouroux \& Amouroux 1986a, 1988); (2) a 'phytoplankton - filter-feeder' system ( $V$. verrucosa + Pavlova lutheri; Amouroux \& Amouroux 1986b, 1988); and (3) a 'benthic diatom - deposit-feeder' system (Abra alba + Navicula incerta, Nitzschia acicularis, and Nitzschia sp.; Amouroux et al. 1989). The aims of the present study were: (1) to use a similar approach to quantify the consumption, the ingestion, and the assimilation of the deposit-feeding polychaete Eupolymnia nebulosa fed on 3 benthic diatoms ( $N$. incerta, $N$. acicularis, and Nitzschia sp.); and (2) to compare these results with those obtained with the same algae for the deposit-feeding bivalve A. alba (Amouroux et al. 1989).

\section{MATERIAL AND METHODS}

Experimental study. Worms: Eupolymnia nebulosa (Montagu) is a very common deposit-feeding polychaete found along the Mediterranean coast of France. Although it is able to colonize very different habitats, this species preferentially lives under large embedded boulders (Grémare 1986, 1988). It is often sympatric with the hesionid Hesione pantherina, and a great proportion of its tubes are also occupied by the commensal polynoid polychaete Polynoe scolopendrina. E. nebulosa feeds on the sediment surface by means of its numerous tentacles (Dales 1955, Grémare 1988). Feeding takes place almost entirely in darkness (Lang 1984, 1986, Gremare 1988). For the present study, the worms were collected by SCUBA diving at a shallow station $(<5 \mathrm{~m})$ located in the bay of PortVendres (western Mediterranean). They were then kept in the laboratory for several weeks in tanks provided with running ambient seawater.

Diatoms: The food provided and the experimental conditions were similar to those described by Amouroux et al. (1989).

The tested food sources were 3 different strains of diatoms: Navicula incerta (Grunow), Nitzschia acicularis (Wm Smith) and Nitzschia sp. (provided by Dr C. Riaux from the Roscoff laboratory, France). N. incerta is $16 \mu \mathrm{m}$ long and contains $5.9 \times 10^{-10} \mathrm{~g}$ of organic matter $\left(500^{\circ} \mathrm{C}\right.$ for $\left.5 \mathrm{~h}\right)$ per cell, $N$. acicularis is $60 \mu \mathrm{m}$ long and contains $1.5 \times 10^{-10} \mathrm{~g}$ of organic matter per cell, Nitzschia sp. is $11 \mu \mathrm{m}$ long and contains $1.1 \times 10^{-10} \mathrm{~g}$ of organic matter per cell.
Diatoms were grown at $18^{\circ} \mathrm{C}$ for $15 \mathrm{~d}$ under constant illumination (1700 lux) in $f / 2$ medium (Guilliard \& Ryther 1962). Cultures were labelled with $\mathrm{NaH}^{14} \mathrm{CO}_{3}$ (CEA) $12 \mathrm{~h}$ before each experiment.

Dissolved substances; filtrates: Absorption of DOM by Eupolymnia nebulosa was studied separately from ingestion of live diatoms. After centrifugation (4000 $\left.\mathrm{rpm}, 30^{\prime}\right)$, the ${ }^{14} \mathrm{C}$ labelled diatoms cultures were deepfrozen $\left(-40^{\circ} \mathrm{C}\right)$, autoclaved (to break the cell walls), and filtered on a $0.2 \mu \mathrm{m}$ filter. Filtrates containing the labelled soluble organic matter were collected, their radioactivities measured and compared with those of filters retaining the particulate organic matter to quantify the concentration in organic matter of the filtrates (this procedure assumes uniform labelling of the diatoms; Amouroux 1984). Although we are aware that the biochemical composition of the filtrates probably differs from that of the natural exudates, we believe that such a DOM is useful for studying recycling phenomena within the experimental chamber.

Experimental procedure: Cultures were centrifuged $\left(4000 \mathrm{rpm}, 30^{\prime}\right)$ and resuspended in filtered seawater, and their concentrations adjusted so as to correspond to a total organic dry weight of $20 \mathrm{mg}$ per flask (these were not readjusted during experiments). Before use annelids were allowed to clear their guts for $24 \mathrm{~h}$ in filtered seawater. Five worms of known size corresponding approximately to a total ash-free dry weight of $500 \mathrm{mg}$ were introduced into each flask immediately after food addition. The experimental set-up consisted of a $3000 \mathrm{ml}$ flask containing $1000 \mathrm{ml}$ of filtered seawater. The liquid medium was mixed by bubbling air gently sufficient for oxygenation, but not disturbing the sedimentation of diatoms (Amouroux et al. 1989). At the outlet, air was passed through $\mathrm{NaOH}$-traps to capture labelled respiratory $\mathrm{CO}_{2}$. Three experiments involving 3 different time exposures $(4,10$, and $48 \mathrm{~h}$ ) were carried out to measure the consumption of Navicula incerta, Nitzschia acicularis and Nitzschia sp. by E. nebulosa. For each run 3 replicates and a control without worms were carried out in darkness at $15^{\circ} \mathrm{C}$. Under these conditions, worms fed and did not seem to be stressed.

Nine (3 series of 3) $4 \mathrm{~h}$ experiments were carried out to assess the consumption of DOM (filtrates) by Eupolymnia nebulosa. Filtrate concentrations were adjusted so as to correspond to a total organic dry weight of $10 \mathrm{mg} \mathrm{l}^{-1}$. Five worms of known size corresponding approximately to a total ash-free dry weight of $500 \mathrm{mg}$ were introduced into each flask immediately after food addition.

At the end of both experiments radioactivity corresponding to 4 compartments (i.e. annelids, particulate organic matter [POM], dissolved organic matter [DOM], and $\mathrm{CO}_{2}$ ) was measured in a Beckman licuid scintillator (see Amouroux 1984, Amouroux \& Amouroux 1986a, b 


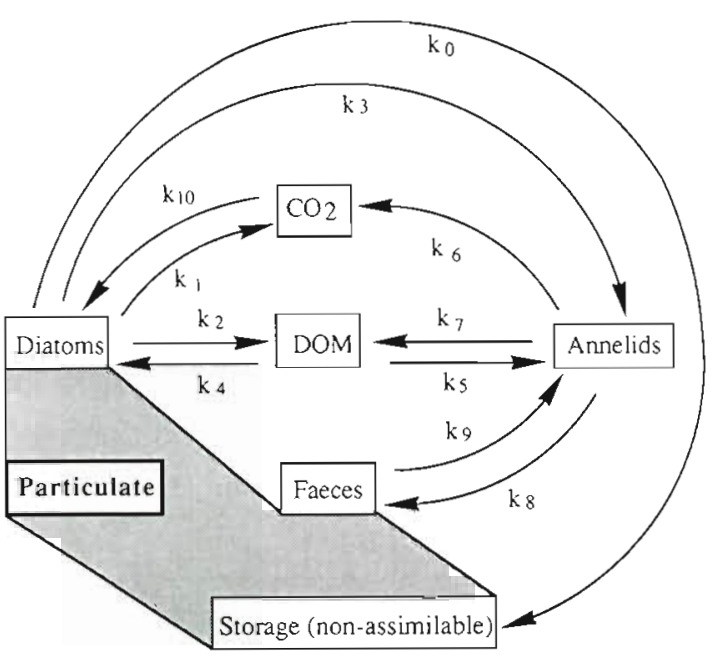

Fig. 1. Six-compartment model of 'Diatom-Annelid' system showing exchanges studied and numbered kinetic constants of mass transfer

for details). In each control, algal cells were resuspended after strongly shaking the flask and then counted on a microgrid. For feeding experiments (i.e. in the presence of annelids) non-ingested diatoms were not counted at the end of the experiments since they were mixed with faeces and biodeposits of E. nebulosa.

Modelling. An analog model was used to calculate the amount of organic matter which passed through the different compartments, and the changes of the radioactivity corresponding to compartments that were not measured experimentally (e.g. non-assimilable storage, faeces). Fitting the model to our experimental data required several trials involving different assumptions. We present here only the model of best fit (i.e. the one which seems to correspond to the most valid hypotheses). The model was used as a tool to test different hypotheses relative to the transfer of matter among the different compartments of the studied system. When the model provided a good description of our experimental data we concluded that our a priori hypotheses (taken into account in the model) were confirmed.

System and difierential equations: The system was closed (Fig. 1); its different compartments were diatoms, annelids, $\mathrm{CO}_{2}, \mathrm{DOM}$, faeces, and NAS (nonassimilable storage compartment corresponding to the accumulation of diatoms in the worm's tube). Each of these compartments should have been analysed separately. However, experimental measurements of radioactivity were carried out in only 4 (i.e. annelids, DOM, $\mathrm{CO}_{2}$ and POM) of these 6 compartments. It was not possible to measure radioactivity corresponding to diatoms and to faeces separately.

Mass transfer dynamics of the 'Diatom-Annelid' system were represented by an interaction of 'kinetic' equations reflecting the rates of exchanges between compartments: $\mathrm{d}[$ Diat $] / \mathrm{dt}=+\mathrm{k} 4[$ Diss $]+\mathrm{k} 10\left[\mathrm{CO}_{2}\right]-\mathrm{k} 1$ [Diat $]-\mathrm{k} 2$ [Diat] - k3 [Diat] - k0 [Diat]

$\mathrm{d}[\mathrm{Ann}] / \mathrm{dt}=+\mathrm{k} 3$ [Diat] $+\mathrm{k} 5[$ Diss] $+\mathrm{k} 9$ [Faec] $-\mathrm{k} 6$

[Ann] $-\mathrm{k} 7$ [Ann] $-\mathrm{k} 8$ [Ann]

$\mathrm{d}[$ Diss $] / \mathrm{dt}=+\mathrm{k} 2[$ Diat $]+\mathrm{k} 7[$ Ann $]-\mathrm{k} 4[$ Diss $]-\mathrm{k} 5$ [Diss]

$\mathrm{d}[$ Faeces $] / \mathrm{dt}=+\mathrm{k} 8[\mathrm{Ann}]-\mathrm{k} 9[$ Faec $]$

$\mathrm{d}\left[\mathrm{CO}_{2}\right] / \mathrm{dt}=+\mathrm{k} 1[\mathrm{Diat}]+\mathrm{k} 6[\mathrm{Ann}]-\mathrm{k} 10\left[\mathrm{CO}_{2}\right]$

$\mathrm{d}[$ Part $] / \mathrm{dt}=\mathrm{d}[$ Diat $] / \mathrm{dt}+\mathrm{d}[$ Faec $] / \mathrm{dt}$

$\mathrm{d}[\mathrm{NAS}] / \mathrm{dt}=\mathrm{k} 0[\mathrm{Diat}]$

where $\mathrm{k} 1, \mathrm{k} 2, \ldots, \mathrm{k} 10=$ kinetic constants of mass transfer, $[\mathrm{X}]=$ radioactive content of Compartment $\mathrm{X}$ as a percentage of the total radioactivity initially introduced into the system; $\mathrm{t}=$ time.

The computer circuit simulating these equations together with kinetic constants is illustrated in Fig. 2.

Determination of kinetic constants: First we studied the sub-system 'Diatoms-DOM-CO $\mathrm{C}_{2}$ '. This sub-system corresponds to the change over time of the specific radioactivity of the diatoms alone (control experiments). Controls allowed the computation of $k 2$ and $k 4$ which correspond to the exchanges between diatoms and DOM, and $\mathrm{k} 1$ and $\mathrm{k} 10$ which correspond to the exchanges between diatoms and $\mathrm{CO}_{2}$. These constants were introduced in the model of the 'Diatom-Annelid' system.

Calculation of the amount ingested and assimilated: Experiments alone did not allow distinction between live diatoms and those rejected in faeces. The computation of the amount of radioactivity consumed, ingested (in a particulate form) and assimilated by the worms required the computation of the cumulated amounts of radioactivity within the different compartments. This could only be achieved through modelling the system. The amount consumed was set as the total of the amount of radioactivity corresponding to the annelids plus their excretory products (i.e. faeces DOM and $\mathrm{CO}_{2}$ ). The amount ingested was set as the difference between total consumption (see above) and DOM absorbed by the annelids. The amount assimilated was set as the difference between total consumption and faeces produced by the annelids.

\section{RESULTS}

\section{Experimental study}

\section{Controls}

Changes of radioactivity within the controls (microcosms containing algae without annelids) have previously been reported (Amouroux et al. 1989). The specific radioactivity of the diatoms declined rapidly, 


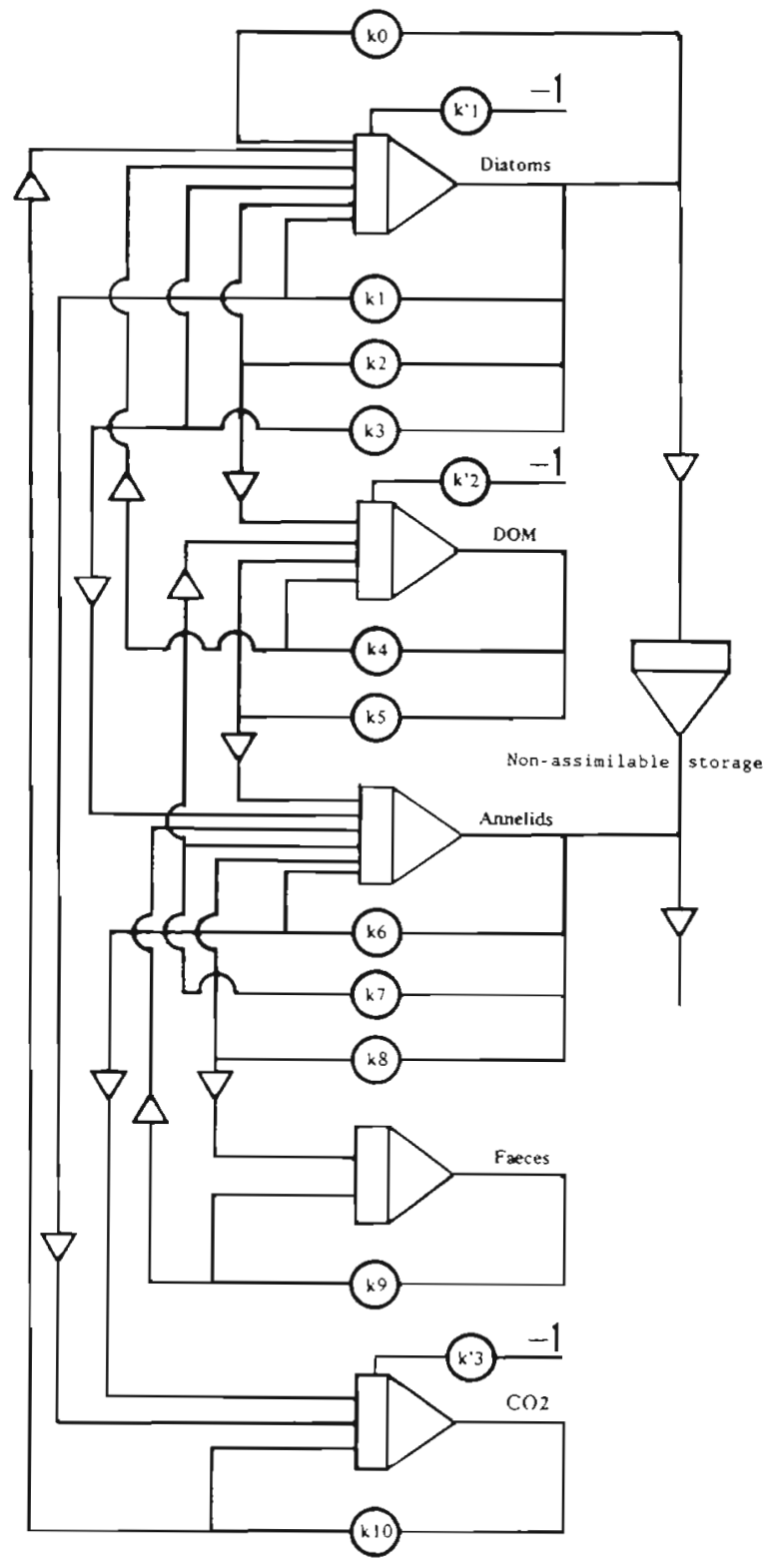

Fig. 2. Circuit diagram of the 'Diatom-Annelid' model

whereas the radioactivity corresponding to DOM and $\mathrm{CO}_{2}$ increased over the first $10 \mathrm{~h}$.

\section{Uptake of DOM (filtrates) by annelids}

After $4 \mathrm{~h}$ the percentages of radioactivity within the annelids were: $3.5,10.4$ and $5.4 \%$ for filtrates of Navicula incerta, Nitzschia acicularis, and Nitzschia sp., respectively.

Consumption of live diatoms by annelids

Annelids incorporated the same quantities (about $20 \%$ after $48 \mathrm{~h}$ ) of the 3 different algae (Figs. 3,4 and

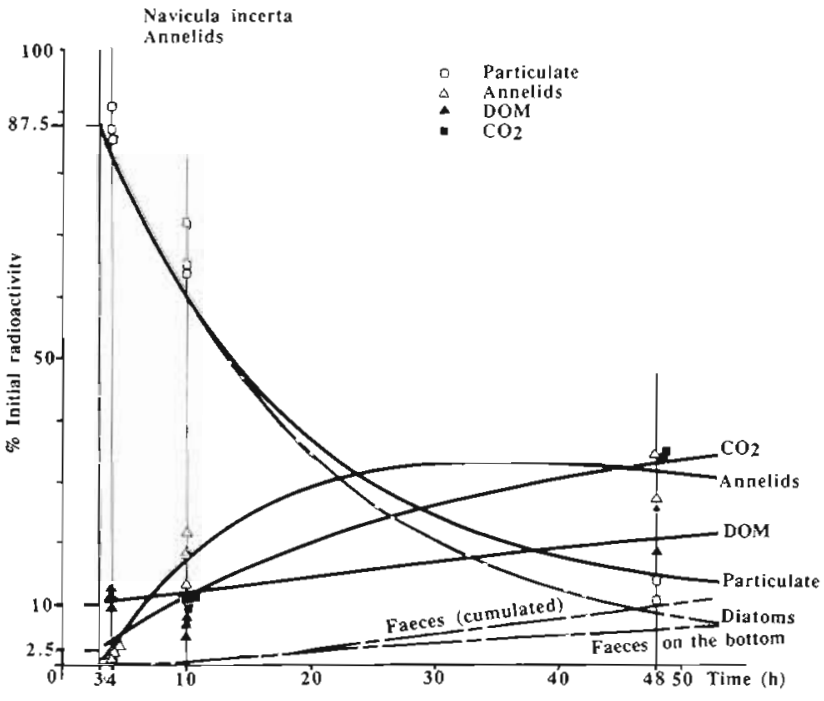

Fig. 3. Time-dependent variation in radioactivity of the different compartments of a 'Diatom-Annelid' system (Navicula incerta-Eupolymnia nebulosa)

5). However, when Eupolymnia nebulosa was fed on Nitzschia acicularis, radioactivity within the particulate matter declined more regularly and siowly than for the other 2 diatoms. For Nitzschia sp., $\mathrm{CO}_{2}$ reached $45 \%$ $(48 \mathrm{~h})$, which suggests a good assimilation and metabolic rate for the ingested food.

\section{Modelling}

Changes in viable diatoms alone over time

The kinetic constants corresponding to the algae alone have been computed elsewhere (Amouroux et al. 1989). These values are given in Table 1.

\section{Consumption of Navicula incerta}

During the first $3 \mathrm{~h}$ of experiments, Navicula incerta was not ingested by Eupolymnia nebulosa. Therefore, the time-origin of the model was shifted by $3 \mathrm{~h}$. At this time (Fig. 6), radioactivity was distributed as follows: $87.0 \%$ in diatoms, $10 \%$ in DOM, and $3 \%$ in respiratory $\mathrm{CO}_{2}$. Radioactivity declined gradually in the particulate fraction (diatoms + faeces) from $87.5 \%(3 \mathrm{~h})$ to $66.5 \%$ $(10 \mathrm{~h})$, and $13.7 \%(48 \mathrm{~h}) . \mathrm{CO}_{2}$ rose from $5 \%(4 \mathrm{~h})$ to $34 \%(48 \mathrm{~h})$. DOM rose slowly from $10 \%(4 \mathrm{~h})$ to $22 \%$ $(48 \mathrm{~h})$. The amount of faeces accumulated on the bottom was low: $5 \%(48 \mathrm{~h})$.

Fitting the model required modification of the values of the kinetic constant (relative to those found in the absence of annelids, Table 1). This suggests that exchanges of $\mathrm{CO}_{2}$ and DOM between algae and water 


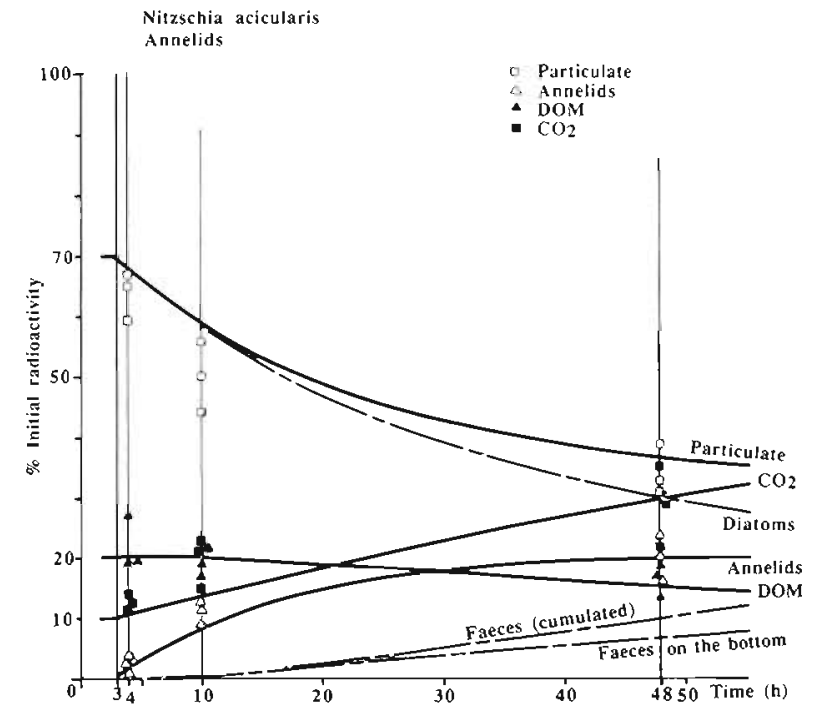

Fig. 4. Time-dependent variation in radioactivity of the different compartments of a 'Diatom-Annelid' system (Nitzschia acicularis-Eupolymnia nebulosa)

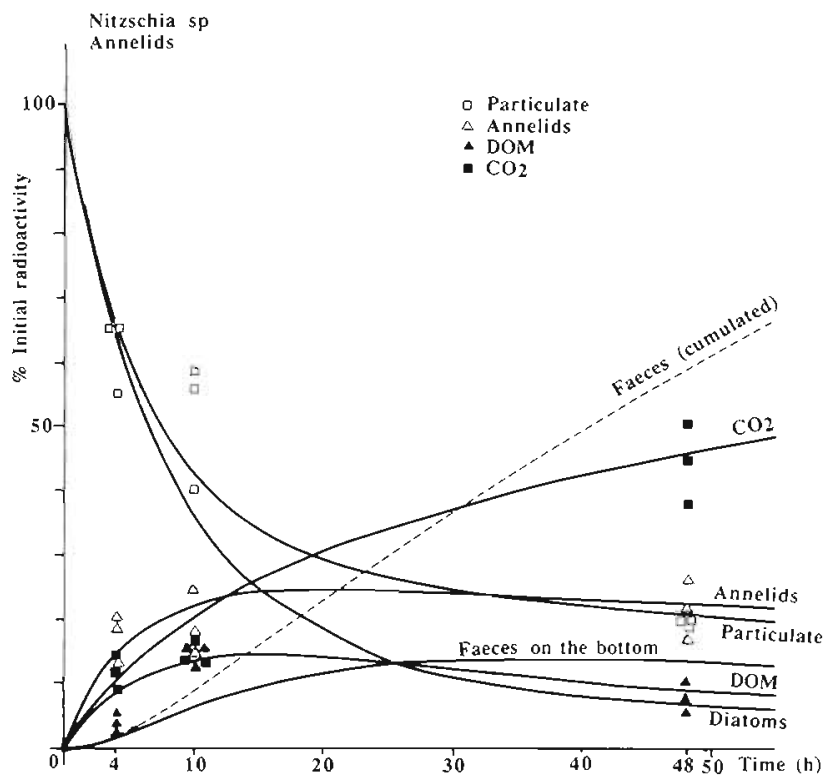

Fig. 5. Time-dependent variation in radioactivity of the different compartmen:s of a 'Diatom-Annelid' system (Nitzschia sp.-Eupolymnia nebulosa)

are affected by the presence of annelids. For the same diatom, we reported a similar result in the presence of the deposit-feeding bivalve Abra alba (Amouroux et al. 1989). k2 (DOM produced by diatoms) changed from 0.0135 to 0.0422 (a 3-fold increase); DOM consumed by the diatoms, $\mathrm{k} 4$, remained fairly constant from 0.0145 to 0.0135 ; the $\mathrm{CO}_{2}$ produced by the diatoms, $\mathrm{k} 1$, changed from 0.0436 to 0.0150 (i.e. 3 times less) and $\mathrm{CO}_{2}$ consumed by the diatoms, $\mathrm{k} 10$, changed from 0.0120 to 0.0345 (a 3 -fold increase)

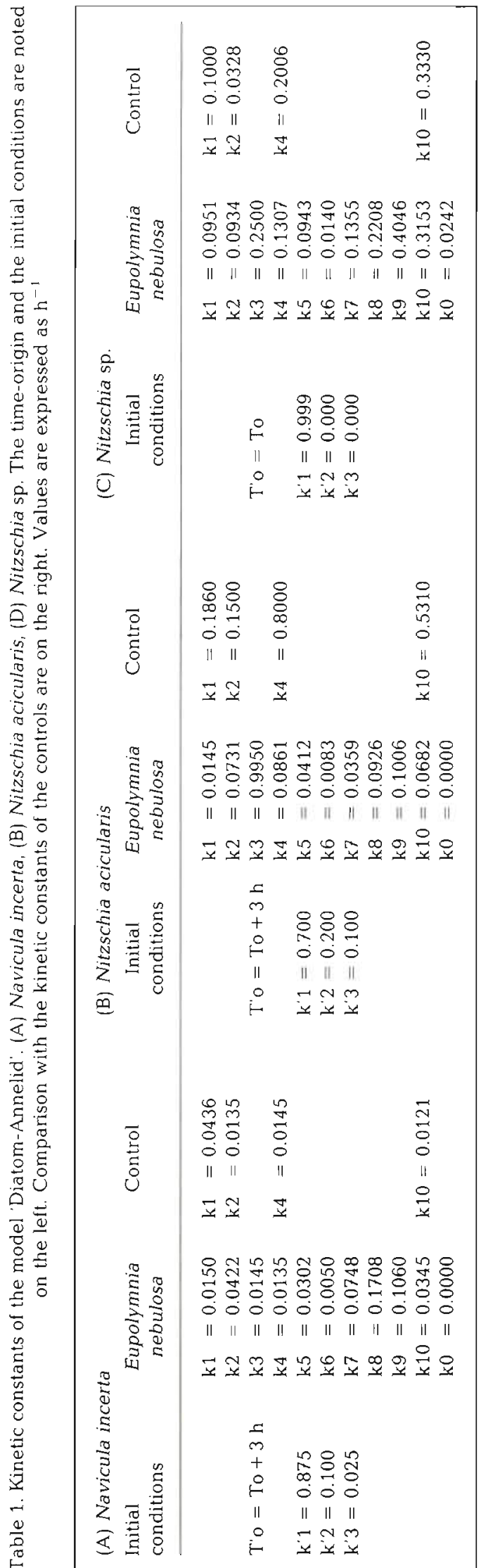




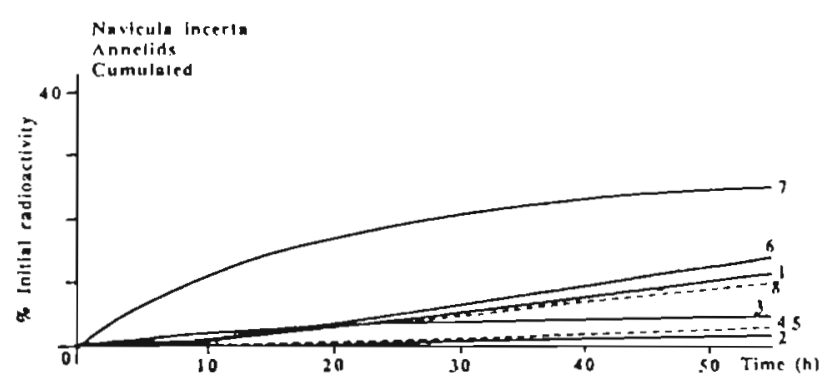

Fig.6. Calculation of cumulated amounts of organic matter (radioactivity) passing through different compartments as a function of time during different exchanges within the Navicula incerta-Eupolymnia nebulosa system. (1) Faeces, (2) $\mathrm{CO}_{2}$ consumed by diatoms, (3) DOM produced by diatoms, (4) DOM consumed by annelids, (5) DOM consumed by diatoms, (6) DOM produced by annelids, (7) $\mathrm{CO}_{2}$ produced by diatoms, (8) $\mathrm{CO}_{2}$ produced by annelids

\section{Consumption of Nitzschia acicularis}

The time-origin of the model was shifted by $3 \mathrm{~h}$. At this time (Fig. 7), radioactivity was distributed as follows: $70.0 \%$ in diatoms, $20.0 \%$ in DOM, and $10.0 \%$ in $\mathrm{CO}_{2}$. Eupolymnia nebulosa consumed Nitzschia acicularis more slowly than Navicula incerta. The amount of radioactivity contained in the annelids rose from $1.9 \%$ $(4 \mathrm{~h})$ to $19.7 \%(48 \mathrm{~h})$. Radioactivity of the particulate fraction declined slowly from $63.8 \%(4 \mathrm{~h})$ to $33.6 \%(48 \mathrm{~h})$. DOM declined from $21.7 \%(4 \mathrm{~h})$ to $16 \%(48 \mathrm{~h}) . \mathrm{CO}_{2}$ rose from $12.6 \%(4 \mathrm{~h})$ to $30.6 \%(48 \mathrm{~h})$. The production of faeces accumulated during $48 \mathrm{~h}$ was low $(7 \%)$. As for $N$. incerta, the kinetic constant of the diatom was affected by the presence of worms (Table 1). The value for $k 2$ changed from 0.1860 to 0.0731 ( 2 times less), $\mathrm{k} 4$ changed

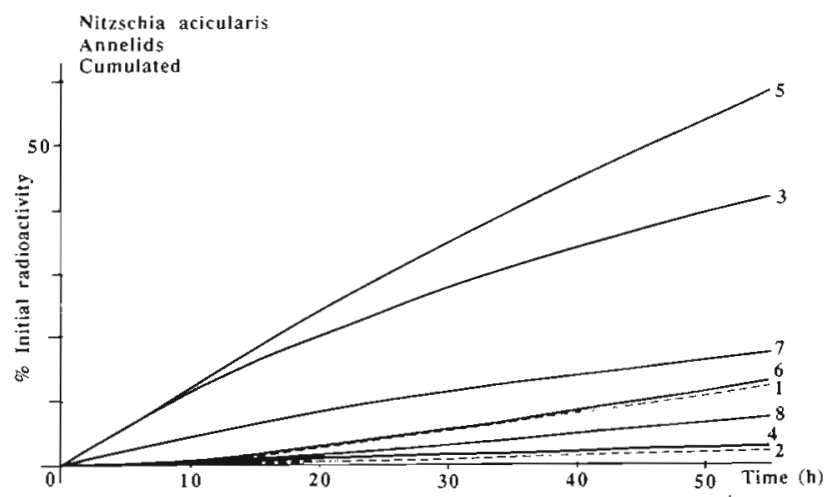

Fig. 7. Calculation of cumulated amounts or organic matter (radioactivity) passing through different compartments as a function of time during different exchanges within the Nitzschia acicularis-Eupolymnia nebulosa system. (1) Faeces, (2) $\mathrm{CO}_{2}$ consumed by diatoms, (3) DOM produced by diatoms, (4) DOM consumed by annelids, (5) DOM consumed by diatoms, (6) DOM produced by annelids, (7) $\mathrm{CO}_{2}$ produced by diatoms, (8) $\mathrm{CO}_{2}$ produced by annelids from 0.8000 to 0.0861 (9.5 times less), $\mathrm{k} 1$ changed from 0.1860 to 0.0145 ( 13 times less), k10 changed from 0.5310 to 0.0682 ( 8 times less).

\section{Consumption of Nitzschia sp.}

The consumption of Nitzschia sp. by Eupolymnia nebulosa began immediately after the food was introduced. Therefore, the time-origin of the model was not shifted. Radioactivity (Fig. 8) in the particulate fraction (diatoms + faeces) declined gradually from $61.3 \%(4 \mathrm{~h})$ to $22.3 \%(48 \mathrm{~h}) . \mathrm{CO}_{2}$ rose from $12.5 \%(4 \mathrm{~h})$ to $45.7 \%$ (48h). DOM rose from $4.3 \%(4 \mathrm{~h})$ to $15.4 \%(10 \mathrm{~h})$ and then declined to $9.6 \%(48 \mathrm{~h})$. Radioactivity of the faeces trapped on the bottom reached $12 \%$ ( $48 \mathrm{~h}$ ). Here again, the presence of $E$. nebulosa affected the kinetic constant of the diatom (Table 1 ). The value for $\mathrm{k} 2$ changed from 0.0328 to 0.0934 (a 3-fold increase), $\mathrm{k} 4$ changed from 0.2006 to 0.1307 (1.5 times less), whereas $\mathrm{k} 1$ and $\mathrm{k} 10$ remained fairly constant $(0.1000$ vs 0.095 , and 0.3330 vs 0.3153 , respectively),

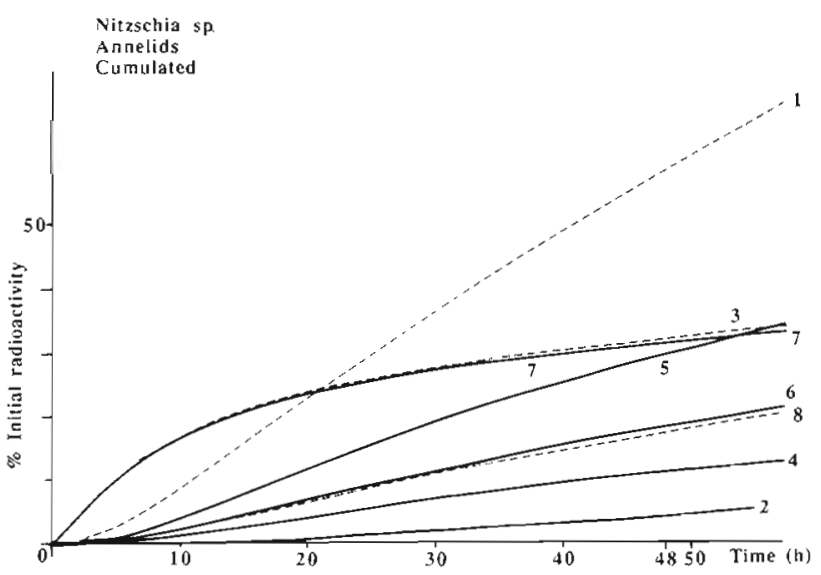

Fig. 8. Calculation of cumulated amounts of organic matter (radioactivity) passing through different compartments as a function of time during different exchanges within the Nitzschia sp.-Eupolymnia nebulosa system. (1) Faeces, (2) $\mathrm{CO}_{2}$ consumed by dratoms, (3) DOM produced by diatoms, (4) DOM consumed by annelids, (5) DOM consumed by diatoms (6) DOM produced by annelids, (7) $\mathrm{CO}_{2}$ produced by diatoms,

(8) $\mathrm{CO}_{2}$ produced by annelids

\section{Consumption, ingestion, and assimilation}

The computation of the amount of radioactivity consumed, ingested (in a particulate form) and assimilated by the worms required the computation of the cumulative amounts of radioactivity within the different compartments. This could only be achieved through modelling of the system. Such cumulative amounts are pre- 
sented for Navicula incerta, Nitzschia acicularis, and Nitzschia sp., in Figs. 6, 7, and 8, respectively.

Nitzschia sp. (Table 2) was the diatom most readily consumed ( $118.5 \%$ vs 63 and $48 \%$ for Navicula incerta and Nitzschia acicularis, respectively), ingested (108\% vs 60.5 and $40.5 \%$ for $N$. incerta and $N$. acicularis, respectively) and assimilated ( $95 \%$ vs 55 and $38.5 \%$ for $N$. incerta and $N$. acicularis, respectively).

Table 2. Comparison of results after fitting the model. For each diatom species the amount of cumulated radioactivity is listed through each compartment after 50 h. (1) Faeces, (2) $\mathrm{CO}_{2}$ consumed by diatoms, (3) DOM produced by diatoms, (4) DOM consumed by annelids, (5) DOM consumed by diatoms, (6) DOM produced by annelids, (7) $\mathrm{CO}_{2}$ produced by diatoms, (8) $\mathrm{CO}_{2}$ produced by annelids. As percentages of initial radioactivity

\begin{tabular}{|c|c|c|c|}
\hline & $\begin{array}{c}\text { Navicula } \\
\text { incerta }\end{array}$ & $\begin{array}{l}\text { Nitzschia } \\
\text { acicularis }\end{array}$ & $\begin{array}{l}\text { Nitzschia } \\
\text { sp. }\end{array}$ \\
\hline \multicolumn{4}{|l|}{50 h cumulated } \\
\hline (1) Faeces & 10.0 & 10.0 & 60.0 \\
\hline (2) $\mathrm{CO}_{2}$ cons Diat & 1.0 & 1.5 & 4.5 \\
\hline (3) DOM prod Diat & 5.0 & 40.0 & 32.0 \\
\hline (4) DOM cons Ann & 2.5 & 2.5 & 10.5 \\
\hline (5) DOM cons Diat & 2.5 & 55.0 & 30.5 \\
\hline (6) DOM prod Ann & 12.5 & 11.5 & 18.0 \\
\hline (7) $\mathrm{CO}_{2}$ prod Diat & 26.0 & 17.0 & 31.5 \\
\hline (8) $\mathrm{CO}_{2}$ prod $\mathrm{Ann}$ & 9.0 & 7.0 & 17.5 \\
\hline \multicolumn{4}{|l|}{50 h present } \\
\hline Faeces & 5.5 & 7.0 & 13.0 \\
\hline Diatoms & 8.5 & 28.5 & 7.0 \\
\hline DOM & 10.5 & 15.0 & 9.0 \\
\hline Particulate & 14.5 & 35.5 & 20.5 \\
\hline Annelids & 31.5 & 19.5 & 23.0 \\
\hline $\mathrm{CO}_{2}$ & 33.5 & 30.0 & 47.5 \\
\hline Amount consumed & 63.0 & 48.0 & 118.5 \\
\hline Amount ingested & 60.5 & 45.5 & 108.0 \\
\hline Faeces produced & 10.0 & 10.0 & 60.0 \\
\hline Faeces recycled & 4.5 & 3.0 & 47.0 \\
\hline DOM consumed & 2.5 & 2.5 & 10.5 \\
\hline Amount assimilated & 55.0 & 38.5 & 95.0 \\
\hline
\end{tabular}

\section{DISCUSSION}

The aims of this study were: (1) to compare ingestion and assimilation of 3 different species of diatoms by the deposit-feeding polychaete Eupolymnia nebulosa, and (2) to compare these results with similar data collected on the deposit-feeding bivalve Abra alba (Amouroux et al. 1989). Our procedure followed the method explained in 2 previous papers (Amouroux \& Amouroux 1988, Amouroux et al. 1989). This study confirms that it is possible to describe the exchanges of matter within a 'benthic diatom - deposit-feeder' system using a compartmental in contrast to an interface model (in which the exchanges of matter between 2 compartments are proportional both to the amounts of matter within the 2 compartments, and to the surface of exchange between the 2 compartments).

\section{Comparison with Abra alba}

Because of several differences (volume of the microcosms, biomass of animals) in the experimental procedures used with Abra alba and Eupolymnia nebulosa, it is not possible to compare directly consumption, ingestion, and assimilation in $A$. alba and E. nebulosa. However, it is possible to compare the effects of these animals on the 3 diatoms.

\section{Ingestion}

The idea that deposit-feeders feed primarily on microbes associated with sediment grains, together with the assumption of the constancy of the ratio between microbial biomass and sediment grain surface (DeFlaun \& Mayer 1983, Yamamoto \& Lopez 1985), has led to the conclusion that smaller particles should be preferentially ingested by deposit-feeders. The theoretical basis of this hypothesis is the optimal foraging model proposed by Taghon et al. (1978). This model was derived from a previous one developed for filter-feeders by Lehman (1976). The main difference between the 2 models is the nutritional value ascribed to each particle, which is described as proportional to its volume for filter-feeders, but to its surface for depositfeeders. Because of this difference, the model predicts the preferential ingestion of smaller particles by deposit-feeders, which has been partly confirmed by further experimental studies (Taghon 1982).

In our experiments the particles themselves constitute the food type. It is reasonable to assume that the nutritive value of one particle is proportional to its volume (see 'Materials and methods'). In this situation the filter-feeder model can be used directly. It predicts a preference for larger particles. A result of this kind has already been reported for the amphipod Siphonocoetes dellavallei fed on 4 different food types (Guidi 1986).

During our experiments with Abra alba, higher ingestion rates corresponded to the larger diatoms (Navicula incerta and Nitzschia acicularis), whereas in Eupolymnia nebulosa, the results were opposite (i.e. ingestion rates of Nitzschia sp. were higher than those obtained with $N$. incerta and $N$. acicularis).

Differences in feeding rates observed in such shortterm experiments reflects the differential efficiency of feeding mechanisms (Boyd 1976, Lehman 1976) Eupolymnia nebulosa is a tentaculate deposit-feeder. 
Upon contact with a suitable particle, its tentacles produce mucus which adheres to the particles allowing their extraction from the surrounding sediment. The particle is then transported to the mouth via the ciliary groove (Grémare 1988). As in most of the other tentaculate deposit-feeders (with the exception of the genera Cistenides and Pectinaria; Whitlatch 1974, Whitlatch \& Weinberg 1982, Dobbs \& Scholly 1986), E. nebulosa preferentially feeds on small particles (Grémare 1988). Abra alba sucks up the thin sediment top layer by movements and numerous distortions of its 4 to $5 \mathrm{~cm}$ long siphons. According to our results, this process probably results in lesser selectivity than for tentaculate deposit-feeders.

\section{Assimilation}

Both in Abra alba and in Eupolymnia nebulosa, Nitzschia sp. is better assimilated than Navicula incerta and Nitzschia acicularis. However, in E. nebulosa the absorption rates (\%assimilated / \% consumed) of the 3 diatoms are almost equivalent $(87.3 \%$ vs 80.2 and $80.2 \%$ for $N$. incerta, $N$. acicularis and Nitzschia sp. respectively), whereas in Abra alba the absorption rate of Nitzschia sp. $(75.6 \%)$ is greater than the absorption rates of $N$. acicularis (56.2\%) and $N$. incerta $(50.9 \%)$. In $E$. nebulosa, differences in assimilation between algae reflect differences in consumption, whereas in $A$. alba differences in assimilation between algae are due to differences in absorption rates.

\section{Effect on the algae}

To obtain a good fit of the model with the experimental data requires some modification of the kinetic constants corresponding to the metabolic exchanges of the algae. This suggests that, while feeding, worms affect diatoms' metabolic rates. Navicula incerta seemed stimulated (increase of $k 2$ and $k 10$ vs a decrease of $k 1$ ). Nitzschia acicularis was inhibited (decrease of $\mathrm{k} 1, \mathrm{k} 2$, $\mathrm{k} 4$, and $\mathrm{k} 10$ ). The results concerning Nitzschia sp. are more difficult to interpret. In this species and in the presence of worms, $\mathrm{k} 1$ and $\mathrm{k} 10$ remained fairly constant whereas $\mathrm{k} 2$ increased and $\mathrm{k} 4$ decreased.

It is interesting that Abra alba and Eupolymnia nebulosa have the same effect on the metabolism of Navicula incerta and Nitzschia acicularis (i.e. inhibition and stimulation, respectively). Nitzschia sp. seemed relatively unaffected by the presence of $E$. nebulosa whereas it was inhibited by $A$. alba. This difference is probably due to the greater rate of ingestion of Nitzschia sp. by E. nebulosa than by $A$. alba.

The inhibition of photosynthetic processes have already been described for a 'periphyton-grazer' sys- tem (Summer \& McIntyre 1982, Moriarty et al. 1985). The reaction of Navicula incerta is more difficult to interpret. As mentioned earlier, experiments were carried out in darkness to limit photosynthesis and to permit a normal activity of worms (Grémare 1988). Dark metabolism of diatoms is not yet well-known. Therefore, the difference between $N$. incerta and the 2 other diatoms could be due to different metabolic adaptations in the 3 species (Gallagher et al. 1984, Mortain-Bertrand et al. 1988).

Finally, it is important to point out, that, at present, we do not know to what extent such interactions between diatoms and deposit-feeders depend on the small size of our experimental system. For example, metabolic products of deposit-feeders may affect growth rate of diatoms, which would cause such an interaction to diminish in a large open system.

\section{CONCLUSION}

Because of the complexity of a 'Food source Deposit-feeder' system, a compartmental analysis coupled with analog modelling is one of the few possible ways of acquiring information on the quantitative aspects of nutrition (ingestion, assimilation, recycling) in some benthic deposit-feeders (i.e. large soft-body tentaculate deposit-feeders).

Our results show that Eupolymnia nebulosa exhibits higher ingestion rates with the smallest diatoms (Nitzschia sp.) whereas in Abra alba feeding rates are independent of diatom size. This is probably due to differences in feeding mechanisms. In spite of such differences, $E$. nebulosa and $A$. alba have the same effect on 2 of the 3 diatoms (stimulation of Navicula incerta and inhibition of Nitzschia acicularis). This suggests that the nature of the response of a diatom to the presence of a deposit-feeder is probably a specific characteristic.

More detailed studies are now needed: (1) to determine (and to compare) the exact effects of depositfeeding organisms on their food sources in the laboratory and in the field, and (2) to quantify actual ingestion and absorption rates of deposit-feeders fed on different food sources.

\section{LITERATURE CITED}

Adams, S. M., Angelovic, J. W. (1970). Assimilation of detritus and its associated bacteria by three species of estuarine animals. Chesapeake Sci. 12: 249-254

Amouroux, J. M. (1984). Preliminary study on the consump tion of dissolved organic matter (exudates) of bacteria and phytoplankton by the marine bivalve Venus verrucosa. Mar. Biol. 82: 109-112

Amouroux, J. M., Amouroux, J. (1986a). Comparative study of 
the carbon cycle in Venus verrucosa fed on bacteria and phytoplankton. 1. Consumption of bacteria (Lactobacillus sp.). Mar. Biol. 90: 237-241

Amouroux, J. M. Amouroux, J. (1986b). Comparative study of the carbon cycle in Venus verrucosa fed on bacteria and phytoplankton. II. Consumption of phytoplankton (Pavlova lutheri). Mar Biol. 92: 349-354

A.mouroux, J. M., Amouroux, J. (1988). Comparative study of the carbon cycle in Venus verrucosa fed on bacteria and phytoplankton. III. Comparison of models. Mar. Biol. 97: 339-347

Amouroux, J. M., Grémare, A., Amouroux, J. (1989). Modelling of consumption and assimilation of Abra alba (Mollusca, Bivalvia). Mar Ecol. Prog. Ser. 51:87-97

Boyd, C. M. (1976). Selection of particle sizes by filter-feeding copepods: a plea for reason. Limnol. Oceanogr. 21: 175-180

Branch, G. M., Pringle, A. (1987). The impact of the sand prawn Callianassa kraussi Stebbing on sediment turnover and on bacteria, meiofauna, and benthic microflora. J. exp. mar. Biol. Ecol. 107: 219-235

Calow, P., Fletcher, C. R. (1972). A new radiotracer technique involving ${ }^{14} \mathrm{C}$ and ${ }^{51} \mathrm{Cr}$ for estimating the assimilation efficiencies of aquatic, primary consumers. Oecologia (Berl.) 9: 155-170

Cammen, L. M. (1980). The significance of microbial carbon in the nutrition of the deposit-feeding polychaete Nereis succinea. Mar Biol. 61: 9-20

Christens, H., Kanneworff, E. (1985). Sedimenting phytoplankton as major food source for suspension and depositfeeders in the Øresund. Ophelia 24: 223-244

Conover, R. J., Francis, V. (1973). The use of radioactive isotopes to measure the transfer of materials in aquatic food chains. Mar. Biol. 18: 272-283

Dales, R. P. (1955). Feeding and digestion in terebellid polychaetes. J. mar biol. Ass. U. K. 34: 55-60

DeFlaun, M. F., Mayer, L. M. (1983). Relationships between bacteria and grain surfaces in intertidal sediments. Limnol. Oceanogr 28: 873-881

Dobbs, F. C., Scholly, T A. (1986). Sediment processing and selective feeding by Pectinaria koreni (Polychaete:Pectinariidae). Mar. Ecol. Prog. Ser. 29: 165-176

Dring, M. J., Jewson, D. H. (1982). What does ${ }^{14} \mathrm{C}$ uptake by phytoplankton really measure? A theoretical approach. Proc. R. Soc. Lond. B 214: 351-368

Gallagher, J. C., Wood, A. M., Alberte, R. S. (1984). Ecotypic differentition in the marine diatom Skeletonema costatum: Influence of light intensity on the photosynthetic apparatus. Mar. Biol. 82: 121-134

Graf, G., Bengtsson, W., Diesner, U., Schulz, R., Theede, H. (1982). Benthic response to sedimentation of a spring phytoplankton bloom: process and budget. Mar. Biol. 67: 201-208

Graf, G., Schulz, R., Peinert, R., Meyer-Reil, L. A. (1984). Benthic response to sedimentation events during autumn to spring at a shallow water station in the western Kiel Bight. I. Analysis of processes on a community level. Mar. Biol. 67: 201-208

Grémare, A. (1986). A comparative study of reproductive energetics in two populations of the terebellid polychaete Eupolymnia nebulosa (Montagu) with different reproductive modes. J. exp. mar. Biol. Ecol. 96: 287-302

Grémare, A. (1988). Feeding, tube-building and particle-size selection in the terebellid polychaete Eupolymnia nebulosa. Mar. Biol. 97: 243-252

Guidi, L. D. (1986). The feeding response of the epibenthic amphipod Siphonocoetes dellavallei Stebbing to varying food particle sizes and concentrations. J. exp. mar. Biol. Ecol. 98: 51-63

Guidi, L. D., Tito de Morais, A. (1983). Ascidian faecal pellets and their utilization by an epibenthic amphipod. J. exp mar Biol. Ecol. 71. 289-298

Guilliard, R. R. L., Ryther, J. H. (1962). Studies on marine planktonic diatoms. I. Cyclotella nana Hustedt and Detonula confervacea (Cleve) Gran. Can. J. Microb. 8: 229-239

Hargrave, B. T (1970). The effect of a deposit-feeding amphipod on the metabolism of benthic microflora. Limnol. Oceanogr 15: 21-30

Hylleberg, J. (1975). Selective feeding by Arenicola pacifica with notes on Abarenicola vagabunda and a concept of gardening in lugworms. Ophelia 14: 113-137

Kofoed, L. H. (1975). The feeding biology of Hydrobia ventrosa (Montagu). 1. The assimilation of different components of the food. J. exp. mar. Biol. Ecol. 19: 233-241

Lang, F. (1984). Etude de l'activité tentaculaire de Eupolymnia nebulosa (Montagu (Annélide polychète): son rôle sur la dynamique de la population et du peuplement. Oceanis 10: 775-784

Lang, F. (1986). Peuplement des fonds durs du bassin maritime de la Rânce, rôle fonctionnel de Eupolymnia nebulosa (Annélide polychète). Thèse Doc., Univ. Rennes

Lehman, J. T (1976). The filter-feeder as an optimal forager and the predicted shapes of feeding curves. Limnol. Oceanogr. 21: 501-516

Lopez, G. R., Cheng, I. J. (1983). Synoptic measurements of ingestion rate, ingestion selectivity, and absorption efficiency of natural foods in the deposit-feeding molluscs Nucula annulata (Bivalvia) and Hydrobia totteni (Gastropoda). Mar Ecol. Prog. Ser. 11: 55-62

Mague, T H., Friberg, E., Hughes, J. D., Morris, I. (1980). Extracellular release of carbon by marine phytoplankton: a physiological approach. Limnol. Oceanogr 25:262-270

Moriarty, D. J. W., Pollard, P. C., Hunt, W. G., Moriarty, C. M., Wassenberg, T J. (1985). Productivity of bacteria and microalgae and the effects of grazing by holothurians in sediments on a coral reef flat. Mar. Biol. 85: 293-300

Mortain-Bertrand, A., Descolas-Gros, C., Jupin, H. (1988). Pathway of dark inorganic carbon fixation in two species of diatoms: influence of light regime and regulator factors on diel variations. J. Plankton Res. 10: 199-217

Smith, B. D., Cabot, E. L., Foreman, R. E. (1985). Seaweed detritus versus benthic diatoms as important food resources for two dominant subtidal gastropods. J. exp. mar. Biol. Ecol. 92: 143-156

Smith, D. F., Horner, S. M. J. (1981). Tracer kinetic analysis applied to problems in marine biology. Can. Bull. Fish. Aquat. Sci. 210: 113-128

Stephens, G. C. (1968). Dissolved organic matter as a potential source of nutrition for marine organisms. Am. Zool. 8: 95-106

Stuart, V., Lucas, M. I., Newell, R. C. (1981). Heterotrophic utilization of particulate matter from the kelp Laminaria pallida. Mar, Ecol. Prog. Ser. 4: 337-348

Summer, W. T., McIntyre, C. D. (1982). Grazer-periphiton interactions in laboratory streams. Arch. Hydrobiol. 93(2): $135-157$

Taghon, G. L. (1982). Optimal foraging by deposit-feeding invertebrates: role of particle size and organic coating. Oecologia (Berl.) 52: 295-304

Taghon, G. L., Self, R. F. L., Jumars, P. A. (1978). Predicting particle selection by tentaculate deposit-feeders: a model and its implications. Limnol. Oceanogr. 23: 752-759

Tenore, K. R. (1981). Organic nitrogen and caloric content of detritus. I. Utilization by the deposit-feeding polychaete Capitella capitata. Est. coast. Shelf Sci. 12: 39-47

Whitlatch, R. B. (1974). Food-resource partitioning in the deposit-feeding polychaete Pectinaria gouldii. Biol. Bull. mar. biol. Lab., Woods Hole 147: 227-235 
Whitlatch, R. B., Weinberg, J. R. (1982). Factors influencing particle selection and feeding rate in the polychaete Cistenides (Pectinaria) gouldii. Mar. Biol. 71: 33-40

This article was submitted to the editor
Yamamoto, N., Lopez, G. R. (1985). Bacterial abundance in relation to surface area and organic content of marine sediments. J. exp. mar. Biol. Ecol. 90: 209-220

Manuscript first received: November 24, 1988

Revised version accepted: March 22, 1989 